DOI 10.20396/temáticas.v20i40.11539

\title{
AS LESBIANIDADES ENTRE O ESTIGMA DA PROMISCUIDADE E DA ILEGITIMIDADE SEXUAL
}

\author{
Livia Gonsalves Toledo* \\ Fernando Silva Teixeira Filho**
}

\begin{abstract}
RESUMO: Este artigo é parte de uma dissertação de mestrado que estudou o modo como estigmas e estereótipos a respeito da lesbianidade influenciam a vida, na esfera da sexualidade, de mulheres que se autodenominam lésbicas. Baseando-se nos estudos de gênero e feministas, questionamos as legitimações da sociedade heteronormativa apresentados como discursos arbitrários sobre a vivência da lesbianidade - a promiscuidade e a ilegitimidade sexual. A partir de entrevistas em profundidade, apresentamos como as participantes da pesquisa (mulheres lésbicas) discursam sobre esse estigma na construção de suas subjetivações, por meio de narrativas de suas histórias de vida. Essa pesquisa foi financiada pela Fundação de Amparo à Pesquisa do Estado de São Paulo - FAPESP, e realizada pelo Programa de Pós-Graduação da Universidade Estadual Paulista - Campus de Assis-SP
\end{abstract}

PALAVRAS-CHAVE: Lesbianidade, Gênero, Heteronormatividade, Promiscuidade, Ilegitimidade.

\footnotetext{
* Mestre em Psicologia pela Universidade Estadual Paulista. E-mail: liviagtoledo@gmail.com.

** Prof. Dr. em Psicologia na Universidade Estadual Paulista. E-mail: fteixeira@assis.unesp.br.
} 
Portinari (1989, p. 15) aponta que "para além de ser maldita, a homossexualidade é, sobretudo, dita" tanto por quem não é homossexual, como por quem é, ou no momento específico de "ser". A relações/práticas homoeróticas entre mulheres, em sendo ditas, e também invisibilizadas, são cercadas de visões generalizadas ou deslegitimantes que permitem a criação de estigmas e estereótipos sobre elas.

Problematizamos aqui dois estigmas atribuídos às mulheres lésbicas: a promiscuidade e a ilegitimidade sexual. Para tal, apresentam-se aqui recortes de entrevistas realizadas com cinco mulheres que se autodenominam lésbicas, três de 18 a 25 anos (Eduarda, Marina e Fernanda), e duas de 40 a 50 anos (Janaína e Marcela ${ }^{1}$ ), residentes em uma cidade $^{2}$ do interior do estado de São Paulo, Brasil. A pesquisa na qual esse artigo se baseia foi financiada pela Fundação de Amparo à Pesquisa do Estado de São Paulo - FAPESP, e realizada pelo Programa de Pós-Graduação da Universidade Estadual Paulista - Campus de Assis-SP.

Ao colher relatos individuais, procura-se, a partir do singular, da individualidade, do vivido e do experienciado, compreender algumas das possibilidades de vivências que fogem ao contexto da sociedade normatizada, ou, ao contrário, compreender como o poder heteronormativo se impõe sobre essa população, muitas vezes acarretando ilegitimidade, marginalização e violência.

\section{“LÉSBICAS: UM 'TIPO' DE MULHER?”}

Lésbicas, antes de tudo, são mulheres, ou seja, aquelas que as participantes da pesquisa classificam como nascidas com o sexo biológico feminino. Não se pode dizer que são mulheres do sistema heterossexual,

\footnotetext{
1 Nomes fictícios.

${ }^{2}$ A cidade tem pouco menos de 100 mil habitantes, situada no Oeste Paulista, de economia rural.

Temáticas, Campinas, 20(40): PG-PG, ago./dez. 2012
} 
aquelas construídas em oposição aos homens e à masculinidade, e com seu desejo sexual direcionado a eles, pois, diferentemente do que é instituído, atraem-se afetivo-sexualmente por mulheres; porém, são construídas no sistema binário de sexo - sentem-se subjetivamente mulheres e incorporam muito do que é dito de "ser mulher", tal como afirma Bordieu (1996, p. 30) sobre a ordem institucional:

[...] podemos nos apoiar sobre a análise de uma ordem institucional que, como toda instituição, existe de duas formas: de um lado, nas coisas, sob forma, por exemplo, de divisões espaciais entre os espaços masculinos e femininos [...], e por outro lado, no cérebro, nas mentes, sob a forma de princípios de visão e de divisão, de taxionomias, de princípios de classificação que assumem freqüentemente a forma, em nossas sociedades, de duplas de adjetivos. [...] tal oposição existe na objetividade, e existe também dentro das cabeças, continuando assim a reproduzir estruturas das quais são o próprio produto.

Ou seja, para compreender o processo de construção social da mulher "é preciso romper com as filosofias da consciência" (Bordieu, 1996, p. 37) e perceber que lésbicas incorporam as estruturas segundo as quais os dominantes as percebem - elas são percebidas e se percebem como mulher.

Em diversos momentos históricos, as mulheres foram sendo vistas desde facilmente "corrompíveis" pelos pecados da carne até naturalmente dóceis, sentimentais, maternais e passivas (social e sexualmente), atributos compreendidos como próprios da feminilidade. Em relação às sexualidades femininas, na época vitoriana, no fim do século XIX, as opiniões social e científica consideravam que as mulheres apenas tinham relações sexuais para cumprir com suas obrigações do matrimônio, sendo, deste modo, quase impensável que tivessem atos sexuais entre elas. Segundo Gimeno Reinoso (2005), em Paris, apenas nos anos 1920 as mulheres começaram a ser vistas como tendo desejo sexual legítimo, coisa que no século XVII 
acreditava-se que apenas as prostitutas tinham. Porém, no caso dos homens, esses sempre foram vistos como detentores de um forte "instinto" sexual.

Dentro da construção social dos gêneros, são os gays a serem qualificados de libertinos, enquanto as lésbicas são entendidas como amorosas e "casamenteiras", o que, no senso comum, reflete na forma como são vistos os seus relacionamentos. Tal como aponta uma piada do meio homossexual descrita por Camille Paglia, filósofa lésbica americana:

\footnotetext{
Você sabe a diferença entre um casal gay masculino e um casal gay feminino? [...] entre homens, o segundo encontro nem chega a acontecer. Mas no segundo encontro entre as mulheres, elas já começam a discutir a relação e a planejar na casa de qual das duas vão morar. (Revista Cláudia, 1998, p. 175)
}

Marcela e Janaína, participantes da pesquisa, concordam que a forma de uma mulher relacionar-se é diferente da dos homens, mas justificam isso devido a uma "essência" masculina ou feminina. Ou seja, que os homens possuem um instinto de não manterem relacionamentos estáveis e serem mais infiéis, em oposição às mulheres que, quando amam, não traem:

[Você acha que na relação entre mulheres tem mais fidelidade?] Tem. Com certeza. Porque a mulher, quando ela gosta, ela gosta! E o homem, não. O homem, ele pode tá amando aqui uma pessoa, mas se passou outra ali, mais bonitinha, mais ajeitadinha, ele já cobiça. [...] Então a mulher, ela é muito fiel. Principalmente quando ela gosta. E amor entre duas mulheres é um amor muito forte, sabia? É muito forte. Não é assim... Porque eu vejo minhas irmãs com meus cunhados, meus irmãos com as minhas cunhadas. Eles têm um amor, mas não é aquele amor, sabe? Você tem aquela pessoa, você tá vivendo ali, pra ela. Esse negócio. E eles não são assim. E a mulher, ela é. Quando ela gosta, ela enfrenta o céu, a terra pra viver aquilo. E o casal, homem e mulher, não. (Marcela, 42 anos) 
Na maioria, eu acho que a mulher, ela, se ela tiver a pessoa que ela gosta, ela não consegue ficar com outra pessoa. Eu vejo dessa forma. A não ser que já tenha desinteressado pela pessoa e que tenha, aí, já começado a haver uma possibilidade de uma válvula de escape, mas eu acredito que com a mulher, não. Talvez o homem seja mais fácil, até pelo instinto do homem. Eu vejo dessa forma. Mas a mulher, não. Eu acredito que a mulher, quando ela gosta de alguém, ela não consegue se entregar pra outra pessoa. Ela não consegue se relacionar intimamente. (Janaína, 47 anos)

Em relação à crença na natureza hipersexual dos homens e na natureza assexuada das mulheres, Castañeda (2006) lembra que "se trata de uma distribuição de papéis socialmente sancionada, mais do que atributos pessoais [e que a hipersexualidade do "verdadeiro homem"] constitui, pelo menos em parte, um mito suplementar do machismo". Ela diz como as sexualidades das mulheres vêm se aproximando da masculinidade nos últimos anos:

[As mulheres] apresentam, cada vez mais, padrões de comportamento semelhantes aos masculinos.Iniciam sua vida sexual mais cedo, praticam mais a masturbação, têm mais companheiros sexuais, mais relações extraconjugais e encontros ocasionais do que algumas décadas atrás. Alguns autores chegaram a falar de 'masculinização' da sexualidade feminina. (Castañeda, 2006, p. 221)

A recusa em pensar que as mulheres possam ser sexualmente ativas, o que rompe com a "essência feminina", faz com que um relacionamento afetivo-sexual entre elas seja visto como assexuado, ou, no mínimo, com poucas relações sexuais. É a partir do "estereótipo de socialização da mulher [...] e a visão idílica das relações lesbianas (seriam relações entre iguais, fora de toda forma de poder)" (Watremez, 2002, s.p.) que se constrói o estigma de que lésbicas possuem uma relação mais de amizade romântica que sexual. 
É importante pensar o papel da mídia na difusão desses estigmas e estereótipos. Borges (2007), em seu artigo sobre telenovelas brasileiras e lesbianidade, lembra que a lesbianidade configura um assunto de alta audiência - lembrando que as telenovelas são abertas ao público e passam em horários em que devem ter programas moralmente aceitos (hetero)normativamente. Portanto, as personagens lésbicas devem corresponder a certos modelos: "não são mais os indivíduos o foco de interesse, mas sim o casal, cuja relação vai sendo apresentada aos poucos" (Borges, 2007, p. 377), as personagens são mulheres brancas, de camadas altas e médias, bonitas, refinadas, escolarizadas ou profissionais, e finalmente, são pouco erotizadas. A partir disso, lembramos o que a autora fala sobre o caráter duplo dos processos de visibilização e invisibilização na mídia: "ao possibilitar a visibilidade de uma determinada posição de pessoa, simultânea e necessariamente outras possibilidades são excluídas e invisibilizadas" (Borges, 2007, p. 373) - ou seja, excluem-se as lésbicas masculinas, pobres, negras, pouco atraentes, e erotizadas (e com este erotismo direcionado a outras mulheres e não ao público masculino, questão que será discutida mais adiante).

Ainda, sobre a visão idílica das relações lesbianas, Castañeda (2007) aponta que os relacionamentos entre mulheres são as que têm menor atividade sexual que os demais casais com o passar dos anos. Para essa autora, isso tem fundamento exatamente na construção social da mulher e na forma como se estabelece a relação entre mulheres, uma vez que ao contrário dos homens, elas não são incentivadas ao exercício erótico e sexual, nem com homens, nem entre si.

A relação lésbica é a menos sexual de todas, e é muito interessante se perguntar por quê. [...] Em primeiro lugar, as mulheres não estão acostumadas a tomar a iniciativa. Lembremos que a sexualidade feminina passa por toda uma socialização que começa muito antes da puberdade. É ensinado às meninas que calem seus desejos e que os subordinem aos dos meninos. [...] Normalmente as mulheres não desenvolvem um papel ativo na sedução, e isso se constata 


\begin{abstract}
em muitos casais lésbicos. Cada uma espera para ver se a outra está com vontade ou não, sem querer insistir demais; [...] Não se deve também esquecer o papel da homofobia interiorizada. É muito mais fácil manter uma relação sexual 'proibida' se for o outro que toma a iniciativa. Até certo ponto, é preciso ter assumido sua sexualidade e aceitado sua parte de responsabilidade na relação antes de poder se doar realmente e expressar seu desejo sem inibição. Outro fator muito importante na sexualidade das lésbicas é que $90 \%$ delas tiveram antes relações com homens [...] muitas dessas mulheres talvez tivessem relações sexuais com homens por obrigação, por interesse, ou para negar sua homossexualidade. [...] se acostumaram a ter relações sexuais sem prazer, ou a reprimir seu verdadeiro desejo: distanciadas de sua sexualidade, terão, naturalmente, dificuldade para gozar dela plenamente, ou para tomar iniciativa em questões sexuais em suas relações homossexuais posteriores. (Castañeda, 2007, p. 224-227)
\end{abstract}

Porém, é importante lembrar que Castañeda (2007), defendendo a tese de uma "psicologia lésbica", isto é, de modos de sentir e pensar típicos de casais de mulheres lésbicas construídos sócio-historicamente, não fez uma análise geracional entre as lésbicas de seu estudo, mostrando possíveis descontinuidades nessa concepção sobre os processos de subjetivação e expressão das sexualidades lésbicas. Entretanto, em nossa pesquisa, algumas entrevistadas também evidenciaram a presença desse estigma sobre as lesbianidades no contexto em que vivem, onde é moralmente mais valorizada a afetividade nos relacionamentos que o desejo sexual:

Às vezes as pessoas fazem uma comparação e falam assim: 'Nossa, mas entre duas mulheres existe muito carinho' - essas coisas todas, né? 'É diferente a relação entre duas mulheres. Porque é duas mulheres, elas se conhecem, praticamente uma sabe a necessidade da outra'. [...] às vezes falam muito bem da relação entre duas mulheres. (Janaína, 47 anos) 
Que... eu vejo também um comportamento, assim, de [as pessoas] achar como se fosse, sabe? Que, por causa disso que as mulheres lésbicas elas não são promíscuas como homens gays. Porque: Porque: 'Nossa! Dois caras só trepam, só pensam em sexo. Agora, as mulheres, não. As mulheres são mais uma coisa, mais assim, um amor espiritual, mais irmandade’. (Eduarda, 18 anos)

No discurso hegemônico, a masculinidade e a atividade sexual são atribuídas aos homens e a feminilidade e a passividade sexual às mulheres, fazendo deles diretamente relacionais. Portanto, dentro dessas representações de gênero e de conjugalidade, as relações lésbicas são vistas dentro de uma perspectiva de romantismo - visto como "natural" à feminilidade - e baixa atividade sexual. Esse parecer vitoriano ocorre especialmente se o casal for composto por duas lésbicas femininas (ladies) - pois a lésbica masculina (sapatão) é tomada como o "macho da relação" e, portanto, a que teria o apanágio da atividade sexual na relação lésbica. Portinari (1989, p. 53), referindo-se às lésbicas sapatão e lady, pontua que essas "seriam justamente as figuras que concedem às lesbianidades uma certa inteligibilidade aos olhos e ouvidos do mundo e da linguagem" heterocentradas.

A crítica do essencialismo de masculinidade/feminilidade como domínio do casal heterossexual sendo o homem detentor da primeira e a mulher detentora da segunda, é evidenciada por Butler (2003a), quando afirma que

A 'presença' das assim chamadas convenções heterossexuais nos contextos homossexuais, bem como a proliferação de discursos especialmente gays da diferença sexual, como no caso de butch e femme como identidades históricas de estilo sexual, não pode ser explicada como a representação quimérica de identidades originalmente heterossexuais. 
Gimeno Reinoso (2005) diz que, para romper o estereótipo assexuado das lésbicas, o modelo sapatão-lady (butch-femme americanas) foi abraçado na década de 1950 nos Estados Unidos, pois a lady, por sua "natureza feminina", era entendida como assexuada ou de baixa atividade sexual. $\mathrm{Na}$ verdade, presas ao sistema hegemônico binário de construção dos gêneros, as sapatões que se utilizavam da masculinidade para legitimar sua atividade sexual, e as ladies que compunham casais com estas pela mesma razão, apenas reforçavam a idéia de que essas últimas, por serem femininas, não detinham tal "capacidade". Justamente por serem invisíveis os casais lady$l a d y$, não se acreditava na legitimidade de tais relações, trazendo segurança ao pensamento machista. "O interesse em sacralizar figuras femininas históricas, mostrando-as como assexuadas, não é mais que a negação de sua sexualidade e, em muitas ocasiões, da lesbianidade presente no processo histórico" (Gimeno Reinoso, 2005, p. 18).

\section{O ESTIGMA DA PERVERSÃO DO HOMOSSEXUAL(ISMO)}

De acordo com Gimeno Reinoso (2005), o feminismo emergente no século XIX em alguns países ocidentais mais industrializados e a reivindicação das mulheres por novos espaços e oportunidades foi visibilizando as relações entre mulheres e evidenciando o que nem se imaginava no século XVII. Assim, as suspeitas de que a impossibilidade de duas mulheres cometerem um "ato imoral" entre elas fosse um equívoco passaram a trazer denúncias com maior freqüência, e as advertências sobre os "perigos" desses vínculos aumentaram.

Um arrepio de terror percorre o mundo ocidental: se as mulheres se educam e podem manter-se economicamente, será difícil que queiram casar-se. Pela primeira vez, o amor entre mulheres ameaça a estrutura social, por isso é muito importante desacreditar as mulheres que se introduzem por esse caminho, e é esse o trabalho que fazem os sexólogos. A mulher que reivindica certos direitos é uma doente, é uma 
mulher que renega seu sexo: uma lésbica. (Gimeno Reinoso, 2005, p. 135)

Essas "desviantes" já eram entendidas pelos especialistas da época (médicos, psiquiatras, psicólogos etc.) como possuindo uma identidade homossexual - não mais apenas atos homossexuais -, ou seja, eram classificadas como doentes a serem curadas. Além da opinião científica, ainda havia a questão da imoralidade trazida do século anterior e, também, o respaldo religioso da idéia de pecado para corromper a imagem das(os) amantes do mesmo sexo. Conforme Marcela lembrou em sua entrevista:

[Já ouvi falar] que [homossexual] não tem vergonha na cara, que onde já se viu isso aí. [Por que você acha que as pessoas pensam isso?] Porque são pessoas antigas. Porque, tem uma passagem na Bíblia, eu não sou crente, não, eu sou católica, mas minha mãe é crente e, às vezes, eu pego a Bíblia em casa, pra ficar lendo. Tem uma passagem lá que fala que teve uma época que Deus acabou com uma, com uma... nem lembro mais que cidade que foi... porque as mulheres começaram a desejar as mulheres e os homens os homens, e aí parou de procriar, parou de nascer filho, e a geração acabou ali. Então ele transformou todinha essa cidade em sal ${ }^{3}$. (Marcela, 42 anos)

\footnotetext{
3 “Quando a Bíblia menciona comportamentos sexuais entre pessoas do mesmo sexo, ela o faz tal como esses comportamentos eram entendidos naquela época. Os ensinamentos da Bíblia só podem ser aplicados hoje na medida em que a antiga compreensão destes mesmos comportamentos ainda for válida. [...] na época da Bíblia não havia uma compreensão mais elaborada da homossexualidade como orientação sexual. Havia apenas uma consciência genérica de atos ou contatos entre pessoas do mesmo sexo, o que poderia ser chamado de homogenitalidade ou atos homogenitais. [...] A simples afirmação de que 'Deus disse que é errado' não é uma resposta boa o suficiente, pois o princípio é válido mesmo em se tratando de Deus: também Deus deve fornecer o motivo pelo qual algo é errado. Isto significa dizer que há bom-senso, que há sabedoria na moralidade exigida por Deus. Se não houver, então toda a moralidade será arbitrária e Deus considerará as coisas como certas ou erradas segundo um capricho divino. Neste caso, toda a reflexão sobre ética deixaria de existir, pois não haveria um princípio racional por traz da moralidade e as exigências de Deus não seriam razoáveis" (Helminiak, 1998, p. 35-36).
}

Temáticas, Campinas, 20(40): PG-PG, ago./dez. 2012 
Foi sendo criada, então, sobre aqueles que tinham atos sexuais nãoreprodutivos, a idéia de perversão sexual, entendida como depravação. Essa "definição da homossexualidade como desvio dos padrões sexuais contribuiu muito para o surgimento da liberação gay" (Rotello, 1988, p. 70) e a criação de uma identidade homossexual. Rotello (1988) pontua que, antes dos anos 1950, apenas os homossexuais masculinos afeminados eram considerados e se consideravam homossexuais. Os homens que praticavam sexo com homens e tinham aparência não afeminada e funções masculinas não eram vistos nem se viam como tal:

Há provas convincentes que antes da metade do século [XX], o comportamento sexual dos homossexuais era muitíssimo diferente do que se tornou mais tarde, de que a partir de meados do século e depois, aconteceram mudanças fundamentais não apenas nas autopercepções e crenças dos homossexuais, como também nos hábitos sexuais, espécies e número de parceiros, e até nas maneiras de fazer sexo. (Rotello, 1988, p. 56)

Nos anos 1960 e início dos anos 1970, nos Estados Unidos, com o crescimento urbano, os homossexuais masculinos criaram uma subcultura que tinha como base de identidade homossexual a relação sexual descomedida:

[...] ocorreram mudanças muito significativas no comportamento gay masculino [...] Entre elas um nítido aumento do sexo anal com parceiros múltiplos, o aparecimento dos assim chamados grupos de alto risco formados por homens que praticavam níveis extraordinários de comportamentos sexual de alto risco, e um rápido aumento na quantidade de intercâmbios sexuais entre pessoas desses grupos de risco e o resto da população gay. [...] As instituições centrais da cultura gay masculina emergente eram os bares e as saunas. [Parte dos gays,] acostumados ao sexo secreto e furtivo, convenceram-se facilmente que a liberação envolvia 
não a abolição da clandestinidade, mas a liberdade de ser tão clandestino quanto possível. [...] se a liberação significava a rejeição da reserva, então, ser mais liberado significava rejeitar ainda mais restrições, e os mais liberados (isto é, os mais gays) eram aqueles sem nenhum tipo de reserva ou restrições. (Rotello, 1988, p. 22)

A partir disso, a idéia de perversão entendida como promiscuidade - além da opinião científica médica de desvio sexual - foi mais usada para qualificar o conjunto sexual dos gays. Por exemplo: "Você acha que os gays são mais promíscuos que as lésbicas?] Com certeza, eles são... eles ficam com o que aparecer e não adianta. Isso eu já vi com meus próprios olhos. Tem os amigos assim que falam pra mim que ficam mesmo e não tão nem ai" (Marcela, 42 anos). Entretanto, mesmo que tenha sido parte de uma subcultura a vivenciar essas relações libertinas, no senso comum essa visão parece ter sido estendida a todos os chamados desviantes da época, inclusive as lésbicas.

Janaína aponta a questão da generalização que se faz daquilo que é chocante ao pensamento moral, e como a homossexualidade é abraçada pelo estereótipo da devassidão e, pautada na idéia de monogamia necessária à boa imagem do relacionamento, defende que aqueles que preferem formas mais liberais de viver seu prazer devem mantê-las no sigilo:

O que a gente ouve muito da relação homossexual, tanto de mulher lésbica, da relação entre mulheres, ou a relação entre homens, é que é tudo uma putaria! Isso é ruim pra gente ouvir. Mas, infelizmente, por causa de alguns, nós somos classificados dessa forma. Porque você sabe que tem meninos que ele tá com um menino aqui, depois quer tá com outro ali, e outro ali. Então, isso vira realmente uma coisa negativa pra gente. Muitos gostam de orgia, essas coisas toda. Eu não acho... pode até gostar, mas não leve isso a público. O que vocêfaz entre quatro paredes você não precisa sair gritando lá fora. E infelizmente muitos agem dessa forma. Então isso deturpa muito, isso cria uma imagem muito negativa em relação ao homossexual. (Janaína, 47 anos)

Temáticas, Campinas, 20(40): PG-PG, ago./dez. 2012 
Publicizar a subversão, como "ficar com várias pessoas", ou "dizer que gosta de orgias", para Janaína, mantém a idéia de homossexualidade como algo promíscuo, esquecendo que tais práticas também fazem parte da vivência heterossexual e sócio-culturalmente construídas com base em uma sexualidade masculina (Weid, 2006) ${ }^{4}$.

A partir dessa generalização que se faz da homossexualidade, os movimentos LGBT pela luta por direitos e combate à discriminação, que cresceram nas últimas décadas, vieram ratificando, entre outros ideais, a concepção da homossexualidade como uma forma de relação que engloba, além do desejo sexual, a afetividade e o desejo de convivência conjunta. Isso permitiu, de certa forma, um abrandamento do sentido de perversão/ doença/devassidão, a partir da valorização da afetividade no casal - tal como nas relações heterossexuais presentes no ideário social. Para Rubin (1998, p. 107), praticamente "todo comportamento erótico é considerado mau, a menos que se estabeleça uma razão específica que o inocente. As desculpas mais aceitáveis são o casamento, a reprodução e o amor [...] ou uma relação íntima duradoura". Assim, a aceitação (ou tolerância) social do casal homossexual pode ocorrer baseada na existência de um sentimento nobre, o amor, existente entre dois seres humanos.

Paiva (2007) vai lembrar Roudinesco $(2003)^{5} \mathrm{e}$ Bordieu (1999) ${ }^{6}$ falando do desejo de muitos homossexuais de uma normalização, ou seja, ser reconhecido e incluído nos laços sociais pelo seguimento das normas de relacionamento aceito - o monogâmico, estável e exclusivista. Essa normalização acaba por trazer uma "invisibilidade" social da homossexualidade em todos os seus formatos estéticos, ou seja,

\footnotetext{
${ }^{4} \mathrm{O}$ trabalho de Weid (2006) busca compreender a prática da troca de parceiros entre casais heterossexuais moradores da cidade do Rio de Janeiro e levanta algumas questões fundamentais sobre as relações, as representações de gênero, os ideais de conjugalidade em nossa sociedade, e especialmente sobre o machismo que permeia essa prática do "swing".

${ }^{5}$ ROUDINESCO, Elizabeth. A família em desordem. Rio de Janeiro: Jorge Zahar, 2003.

${ }^{6}$ BORDIEU, Pierre. Algumas questões sobre o movimento gay e lésbico. In: Pierre. A dominação masculina. Rio de Janeiro: Bertrand Brasil, 1999.
} 
a ilegitmação de uma homossexualidade não "conjugal, monogâmica, branqueada, classe média urbana, psicologizada" (Paiva, 2007, p. 24) - aquela marginal, e periférica, aqueles que se "opõem à ética da reserva e da invisibilidade" (Paiva, 2007, p. 24).

Esse desejo de normalização, segundo Paiva (2007), surge de uma singularização de uma identidade deteriorada, quando se cristalizam representações negativas e rígidas sobre o homossexual e suas relações, baseadas na própria heteronormatividade. Da mesma forma, as inscrições dos relacionamentos de homossexuais nas suas micro-redes de relacionamento (família, amigos, colegas de trabalho etc.) são feitas em um "espaço intersticial de um visível jamais abordado [em] uma complexa tensão entre reconhecimento e silêncio [...] uma visibilidade dos interstícios e não uma visibilidade ostensiva." (Paiva, 2007, p. 29).

$\mathrm{O}$ autor diz que o desafio "consiste em desconstruir os preconceitos que rondam a homossexualidade e ao mesmo tempo não reinvesti-los nessas formas minoritárias, segundo uma lógica do narcisismo das pequenas diferenças" (Paiva, 2007, p. 41), ou seja, não reinvestir somente nos casais aceitos pelo sistema heteronormativo.

A partir disso, pode-se pensar sobre a questão do casamento entre pessoas do mesmo sexo. O pedido de aprovação deste é discursivamente baseado na questão de conferir ao par um parentesco outorgado legalmente. Porém, Butler (2003b, p. 224) aponta que a petição ao direito do casamento seria o mesmo que interpelar o Estado como "detentor de um direito que, na verdade, deveria conceder de maneira não discriminatória, independente de orientação sexual". Além disso, indiretamente, há um reforço do matrimônio como condição única de acesso à cidadania, que poderia, e eticamente deveria, ser direito de todos os cidadãos e cidadãs.

Por que não existiriam maneiras de se organizar os direitos de atenção à saúde de modo que todos, independente do estado civil, tenham acesso a eles? Se defendermos que o casamento é uma maneira de assegurar esses direitos, não estaríamos afirmando também que um direito tão importante 
quanto a atenção à saúde deve continuar sendo alocado com base no estado civil? Como isso afeta a comunidade d

$\mathrm{O}$

$$
\mathrm{s}
$$

não-casados, dos solteiros, dos divorciados, dos nãointeressados em casamento, dos não-monogâmicos - e como o campo sexual torna-se assim reduzido, em sua própria legibilidade, se o casamento se torna a norma? (Butler, 2003b, p. 231)

A autora ainda complementa que "o casamento conduz, pelo menos logicamente, ao reconhecimento universal: todos devem deixá-lo adentrar a porta do hospital, todos devem honrar sua reivindicação de pesar; todos respeitarão seus direitos naturais sobre um bebê; todos considerarão sua relação como elevada para a eternidade" (Butler, 2003b, p. 234). "A preocupação centra-se na tendência para encaixar gays e lésbicas num suposto logos heterossexual do contrato de casamento, da coabitação obrigatória, da fidelidade e dos deveres econômicos." (Almeida, 2006, p. 22).

Porém, Almeida (2006) fala de uma existência real de casais homossexuais, de situações de homoparentalidade, de transformações nas relações de gênero, nas conjugalidades, nas sexualidades, nos mecanismos de reprodução humana, e nas noções de tutela e responsabilidade das e para com as crianças. Assim o autor continua dizendo que:

E agora existem também Estados-nacão onde estas realidades, além de corresponderem a práticas e além de terem significado para os seus actores e actrizes, gozam do reconhecimento pelo poder legitimado. É justamente este reconhecimento pelo Estado que dá importância ao tema, por transportá-lo do campo das práticas dispersas para o espaço público e para o contrato social - e nisso discordo do receio expresso por Judith Butler (2003) de estarem gays e lésbicas a entregar-se à tutela do Estado. (Almeida, 2006, p. 23) 
Não estamos corroborando que a instituição do casamento não deva ser questionada e que deva se tornar norma e forma de legitimar a sexualidade, pois a luta contra a homofobia não precisa se dar nos termos hegemônicos. O que é importante lembrar é que na não-aceitação da legalização das parceiras homossexuais, temos como base uma suposta ameaça à família, "à reprodução biológica, à divisão tradicional de poder entre o homem e a mulher na família e na sociedade e, sobretudo, à manutenção dos valores e da moralidade responsáveis por toda uma ordem e visão de mundo" (Miskolci, 2007, p. 105).

Ainda, instituir o casamento como norma traz realmente o risco da estigmatização: "criar uma distinção entre 'gays de primeira' (casados) e 'gays de segunda' (não casados e acusáveis de promiscuidade)" (Almeida, 2006, p. 22). O que essa distinção nos faz pensar é que o reconhecimento da sexualidade homossexual é ainda incabível no sistema heteronormativo. "A sexualidade de gays e lésbicas rompe com a associação entre sexo e reprodução, o que levava à suspeita de que ela não tem controle nem pode ser socialmente responsável" (Miskolci, 2007, p. 118). Tal fato é corroborado por "tolerantes" falas populares, como: "eu aceito, mas eles/elas não precisam se beijar em público". Ou seja, eliminando-se o erotismo, permite-se que essas pessoas se relacionem casta e invisibilizadamente dentro de um relacionamento monogâmico e estável. Como coloca Louro (2000, p. 29-30), "de acordo com a concepção liberal de que a sexualidade é uma questão absolutamente privada, alguns se permitem aceitar 'outras' identidades ou práticas sexuais desde que permaneçam no segredo e sejam vividas apenas na intimidade".

Ainda é importante falarmos aqui de outra particularidade da construção da identidade lésbica que tem a ver com o que Oliveira (2007) salienta em seu texto sobre a questão da interseccionalidade das identidades a partir de outros marcadores sociais como raça/etnia, classe social, orientação sexual, nacionalidade etc. Ela vai nos dizer que o gênero cruzase com outras identidades (no caso específico de seu texto a identidade negra), e que quando pensamos em construção de identidade, já que não se é, por exemplo, lésbica, branca, rica e instruída, do mesmo modo que se 
é lésbica, negra, pobre e semi-analfabeta. Mais, ainda, ela aponta para outro fator importante já trabalhado por Sedgwick ${ }^{7}$ que é a questão do "armário". Conforme posto por Sedgwick (apud Oliveira, 2007, p. 386) a partir do século XIX, a homossexualidade "tornou-se tema de interesse público e, ao mesmo tempo, um assunto íntimo, privado, que possibilitaria aos homossexuais decidir ou não por revelar-se". Nesse sentido, a identidade de gênero irá ser regulada por esse dispositivo de aprisionamento/proteção que é o armário, o qual em ambientes mais homofóbicos pode se fechar ou até mesmo escancarar-se visando o enfrentamento da situação. De qualquer modo, sempre se passará a questão daquilo que se supõe ser uma pessoa homossexual? Como a definimos? Quais marcadores utilizamos para identificar a diferença entre uma identidade e outra?

Portanto, se de um lado o casamento reitera o binarismo e a heteronormatividade nas pessoas identificadas como homossexuais, ele também é usado como uma maneira de se sair do armário, que visa a desconstruir essa heteronormatividade. Vemos então uma relação paradoxal do uso e efeitos do casamento junto às pessoas homossexuais que faz com que essas corram o risco, por um lado, de entrar em um outro armário, a saber, o da homonormatização, mas também visibilisa a própria homossexualidade afrontando a injúria (Eribon, 2007, p. 27-30) provocada pela heteronormatividade.

Porém, o que queremos salientar aqui é que, além das interseccionalidades de identidades de gênero, orientação sexual, raça/etnia, classe social, etc., estamos falando de seres humanos. Isto é, uma categoria historicamente construída que é a categoria humano e que na pós-modernidade iguala a todos nós independentemente de raça, credo, cultura etc. Enquanto a homofobia, o racismo, o machismo e outras formas de segregação "des-humanizam" as pessoas - colocando-as nas categorias de abjetas (Butler, 2003a) -, a existência real do amor, enquanto direito inalienável do humano, é o que as insere na categoria humana,

${ }^{7}$ Sedgwick, Eve K. A epistemología del armario. Barcelona: Ediciones de la tempestad, 1998. 
independentemente de sua posição social identitária. É a partir dessa articulação do afeto com os direitos que pensamos que a conjugalidade lgbt pode ser compreendida como queer, já que ela também pode representar " a troca de uma política de identidade por uma política da diferença" (Gomide, 2007, p. 416).

As pessoas LGBT também desejam se casar apenas porque amam, e amar é uma prerrogativa humana, e não exclusiva da pessoa heterossexual. Gomide (2007, p. 416) fala, em acordo com a teoria Queer, que:
a identidade gay e lésbica pode acabar por reforçar a hege monia heterossexual, uma vez que são construções identitárias que apenas funcionam em um contexto binário homo/ heterossexual. O Queer, por sua vez, retrataria uma identidade sem essência, ambígua, relativa, uma categoria intuitiva.

Ou seja, as nuances que o quer pode revelar a partir do abalo às identidades passam pela questão do amor (sentimento/sensação/intuição/ querência/desejo) conectado ao conceito de ser humano e seus direitos. O queer pode ajudar a demonstrar que há uma conexão (necessária?) para a definição do humano que passa pelos afetos do amor. Portanto, o que apontamos é que entre o risco da volta à heteronormatividade pela via da homonormatividade há também pessoas LGBT que desejam o casamento como dispositivo de marcação social que revela o amor e, por conseqüência, revela suas humanidades indissociadas a seus direitos. Cremos que todas as pessoas e casais devem ter eticamente acesso e direito à cidadania, tanto no livre exercício de sua sexualidade como no reconhecimento de seus relacionamentos e parcerias, não necessariamente pela via de um casamento formal, mas de outras reconfigurações legais estabelecidas em prol de todos. Entretanto, acima de tudo, acreditamos no direito ao reconhecimento da humanidade de vidas que estão dentro e fora da moral sexual vigente. Acima dos direitos civis, os direitos humanos. Por fim, o importante é que para se dizer que vivemos em uma sociedade com direitos iguais, esse direito de celebração do amor pela via do casamento precisa estar disponível 
a todos e todas independentemente de suas identidades de gênero e orientações sexuais. Façam uso dele quem assim o desejar, pelo simples fato de que, posto como direito, isso se torna possível e realizável.

\section{LÉSBICAS E DOMINAÇÃO MASCULINA}

Os discursos reiterados sobre as lesbianidades são amplamente pautados na dominação masculina. Se, por um lado, a mulher é entendida como desprovida de desejo sexual, a relação lésbica é deslegitimada na visão idílica assexuada, e se, por outro, é vista com desejo sexual legítimo, as lésbicas são entendidas como promíscuas e sua relação é posta a serviço do prazer dos homens.

Eduarda conta como sua mãe julgava a lesbianidade que suspeitava nela, mostrando que a relação entre mulheres não foge a categorização de promiscuidade:

Às vezes ela ficava um tempo quieta, sem nem falar comigo, e, às vezes, ela explodia. Por isso ela me perguntou se orgia com mulher se era bom. Aí eu ficava quieta, ou, às vezes, eu respondia que não... que era um absurdo, de onde ela tinha tirado essas idéias? (Eduarda, 18 anos)

As sapatões parecem ser mais vítimas de tal imagem, por assumirem uma masculinidade estereotipicamente, tendo mais possibilidades de serem vistas como promíscuas e com maior atividade sexual (características socialmente classificadas como masculinas): "eu acho que a maioria das pessoas que têm preconceito, geralmente homem, com uma mulher machinho assim, acha que é uma orgia... um antro" (Marina, 23 anos).

Esse discurso sobre orgia e antro remete à visão da lésbica pornográfica - outro rótulo que se estabeleceu para reforçar a idéia de dominação das mulheres pelos homens, considerando o relacionamento 
entre elas, e para o prazer delas, como ilegítimo. É nesse contexto que as ladies se tornam vítimas da imagem de lésbica promíscua. $O$ ato sexual entre mulheres é compreendido, quando ocorre, para o prazer dos homens:

À mulher' cabe o papel de objeto de desejo, enquanto o homem o de portador do olhar. Neste sentido a homossexualidade feminina serve de estimulo para o olhar masculino, e nem aqui numa relação homossexual feminina o homem pode estar fora, ele aparece como expectador ativo de um espetáculo feito para ele (Lessa, 2004, s. p.)

Weid (2006), em seu estudo sobre casais heterossexuais que freqüentam casas de "swing", conta que ao longo do trabalho de campo, ouviu "muitas vezes que a grande fantasia sexual de todo homem é 'transar' com duas mulheres. Mais do que uma possibilidade, as mulheres são estimuladas pelos seus maridos a experimentarem o bi feminino". Ela aponta que, tanto para os homens como para suas parceiras, o maior prazer em fazer o "bi feminino" é dar prazer ao homem enquanto espectador. A "referência é o desejo do marido" (Weid, 2006, p. 6). Gimeno Reinoso (2005, p. 100-101) aponta como essa visão do ato sexual entre mulheres estar a serviço dos homens já vinha se estabelecendo há alguns séculos:

De fato, no século XVII abundam as descrições pornográficas de sexo entre mulheres na literatura européia, especialmente inglesa e francesa. O erotismo feminino se faz, definitivamente, espetáculo até o ponto em que muitos autores teatrais assumem que um pouco de lesbianismo contribui para chamar a atenção do público masculino; nada se sabe do que pensava o público feminino. Este lesbianismo contado pela ótica masculina, e que já não se oculta, terá conseqüências que se prolongarão no tempo já que estes escritores contribuem com suas criações para fixar um modelo de lésbica e de relações lésbicas que chegou até os dias de hoje. 
A autora ainda lembra que, da mesma forma que a imagem da lésbica masculinizada surge para tornar anormal a mulher que, supostamente, entra no espaço masculino, a imagem da lésbica pornográfica surge para diminuir a ansiedade dos homens frente à possibilidade de existirem mulheres que não se submetem ao controle do viriarcado ${ }^{8}$ e não necessitam deles sexualmente. Essa visão pornográfica é também clara nos vídeos pornôs que mostram atos sexuais entre mulheres: não só nenhuma das parceiras assume características ou estereótipos masculinos - pois não é o que excita a libido dos homens - como ambas relacionam-se sexualmente mediante a penetração por instrumentos fálicos. Ao final, a relação entre elas termina quando um homem surge para "socorrer" uma delas, geralmente a mais bonita e feminina, que deseja veementemente ser penetrada por ele. " $\mathrm{Na}$ produção pornográfica é mesmo comum relações entre mulheres, à espera de um homem, quando então o 'verdadeiro' sexo começa" (Navarro-Swain, 2004, s. p.).

Marcela e Marina exemplificam a visão masculina das mulheres e da relação sexual lésbica como objetos para seu prazer:

Ah, é tanta coisa que você só rindo... [risos] O cara chegar, ficar insistindo pra ficar comigo, e eu falo mesmo, assim, eu falar: "Eu não vou ficar com você...". E falar: "Mas por quê?". E eu falar: "Eu sou lésbica". E ele: "Ah, então arruma aí pra gente fazer um sexo a três"?". Aí eu até falo: "Acha uma aí então pra ver se rola" e aí o cara fica louco, né? [risos] e acha que vai ficar porque é lésbica, entendeu? (Marina, 23 anos). Mas de coisa assim também que você ouve na rua, um bando de mulher andando junto, e você ouve principalmente de

\footnotetext{
${ }^{8} \mathrm{O}$ termo viriarcado, proposto por Nicole-Claude Mathieu (apud Welzer-Lang, 2001), vem como um substituto do conceito do patriarcado, pois este, ao definir o poder dos pais sobre as mulheres e crianças, apesar "de pretender ser um conceito descritivo da dominação masculina, ele sofre, por não dar o devido valor às mudanças nas relações sociais de sexo e, em particular, às modificações se referem às relações de poder" (Welzer-Lang, 2001, p. 475). Assim, o conceito de viriarcado "define como o poder dos homens, sejam eles pais ou não, que as sociedades sejam patrilineares, patrilocais ou não” (Welzer-Lang, 2001, p. 476).
} 
homem: 'Ô, dá umapramim, tem tantas...' Sabe? 'Paga uma... faz uma toca' [faz um sexo oral em mim] Sabe? Podre, que geralmente vem de homem. Não que eu ache que homem é podre, mas vêm deles assim. (Marina 23 anos)

E a gente chegou no estacionamento, a Raquel estava beijando a menina, e um cara, quatro caras tavam chegando. E tava tarde, era umas quatro horas da manhã, todo mundo indo embora. Aí eu falei: 'Entra no carro'. E a Raquel e as meninas foram para o banco de trás e eu sentei no carona, na frente, com a Silvinha do lado. O cara falando: 'Olha o carro, cheio de mulher. E mulher que fica com mulher, vamos dividir aí. Tá fraco o negócio!' E o cara chegou do lado do carro e veio pegando no meu braço. E eu não gostei mesmo, que eles tavam invadindo, né? (Marina, 23 anos)

Isso aí já aconteceu várias vezes na minha vida. Outro dia mesmo, um cara falou assim pra mim: 'Olha, eu tenho uma amiga minha, você não transa com ela na minha frente e tal?’. Eu falei: 'Capaz!'. [...] Não critico também quem faz, cada um que faz da sua vida o que acha melhor. [E você já passou por uma situação complicada por conta disso?] Já teve homem que já ofereceu até dinheiro pra fazer um negócio desse. (Marcela, 42 anos)

Para Castañeda (2006, p. 278-279),

O que antes era considerado próprio das prostitutas, a disposição em trocar sexo por dinheiro, agora se considera provável, ou ao menos possível, em todas as mulheres. Dois fatores contribuíram para difundir essa visão distorcida. Por um lado, a revolução sexual, a 'descoberta' de que as mulheres têm uma sexualidade própria, com necessidades e desejos tão profundos quanto os dos homens, foi interpretada como um convite à libertinagem. Por outro, a indústria pornográfica levada ao paroxismo reforçou a idéia de que as mulheres estão sexualmente disponíveis para todos que possam comprá-las. [...] O cerne da questão não está numa falta de comunicação 
entre os indivíduos, mas na percepção social das mulheres como objetos de consumo.

Rubin (1975), em sua análise feminista das causas da opressão das mulheres em Tráfico de Mulheres, sobrepondo os trabalhos de Claude LéviStrauss e de Sigmund Freud, mostra como um aparato social sistemático as coloca como matéria-prima e as modela domesticadas como produtos. O que é interessante pensar aqui é que os discursos de Marina e Marcela acima apresentados nos apontam o quanto ainda existe a perspectiva das mulheres serem vistas como objetos de troca entre os homens.

Para finalizar, ainda há mais um relato de Marina, que ouvimos freqüentemente sobre as mulheres lésbicas: "Tem uns amigos meus que a gente troca a maior idéia, conversa numa boa, que, às vezes, olha assim: 'Que desperdício!' Também rola esse tipo de comentário"(Marina, 23 anos). Sobre essa última narrativa, mesmo que mais educado que o primeiro, questiona-se: Desperdício do quê? Pra quem? Seria o desperdício de um útero reprodutivo para a proliferação da espécie? Ou desperdício de uma mulher disponível aos homens? O desperdício de um corpo disponível e obrigado a dar prazer aos corpos masculinos?

\section{AS LESBIANIDADES RE-SIGNIFICANDO A "IDÉIA DE MULHER”}

Watremez (2002, s.p.) afirma que "a ideologia do amor condiciona socialmente as mulheres, prescrevendo-lhes o modelo do amor de fusão (equivalente à abnegação) e a dedicação aos outros (sinônimo de altruísmo)" . Castañeda (2006), contudo, deixa claro que nem a fidelidade é um atributo natural das mulheres, nem a iniciativa sexual é um atributo natural dos homens. É devido a essa mesma construção social em que homens e mulheres estão inseridos, que elas parecem ter relações (com os homens ou entre si, afetivo-sexuais ou não) mais baseadas na igualdade, e os homens maior liberdade de sentirem-se no privilégio de usufruir da "tentação": 
[As mulheres] tendem, ao contrário [dos homens], a estabelecer relações igualitárias: geralmente buscam mais o acordo que o desacordo, embora não tenham na realidade a mesma opinião. Quando duas mulheres se conhecem, detectam rapidamente o que têm em comum, compartilham suas histórias e interessam-se mais pelo que as reúne do que pelo que as separa; a conexão horizontal é mais importante para elas que a hierarquia vertical (Castañeda, 2006, p. 31).

Fernanda confirma isso ao falar sobre a questão da durabilidade dos relacionamentos entre mulheres: "Relacionamento de mulher dura mais... eu acho. Pelo que eu vejo, assim, sabe? Homem com homem parece que não pára um com o outro, sabe? Até hoje, eu só vi um casal de gay que durou sete anos, mas de mulher, não, dura bastante". Heilborn (2004), em sua pesquisa sobre conjugalidades modernas marcadas pelo ideal da simetria, compara os relacionamentos de casais de heterossexuais, de gays e de lésbicas de segmentos de camadas médias da Zona Sul do Rio de Janeiro, na faixaetária de 35 a 45 anos. Seu estudo confirma que o casal de mulheres é o que aparece como mais marcado por um intenso companheirismo, com ênfase no apoio psicológico mútuo, e, dentre os demais casais (gay e hetero), o que mais parece ter durabilidade e estabilidade, havendo maior retraimento doméstico. Ela diz que, diferentemente dos gays, que têm uma "possibilidade valorada de contatos sexuais [...] as mulheres homossexuais apresentam uma homogamia social radical" (Heilborn, 2004, p. 188).

Todavia, se Fernanda pontua sobre a durabilidade das relações entre mulheres, ela não diz de uma necessária monogamia, mostrando transformações nas formas de relação entre mulheres em seu círculo social. $\mathrm{Na}$ crítica a algumas amigas lésbicas, Fernanda relata a instabilidade de algumas relações dentro do grupo (composto por mulheres de sua idade aproximadamente), inclusive com ela:

Tipo, eu começo a ficar com alguém e vai lá e dão um jeito de tesourar. [...] a gente sai, conversa, dá risada, um fala mal do outro, uma canta a mulher da outra, ixe, é assim. [...] 
Fica assim com esses papo aranha, assim. [De dar em cima da namorada da outra?] É falar da outra lá, tipo: 'A fulana de tal tava dando em cima de não sei de quem.... Esse tipo de conversa besta, entendeu? [Não, me explica melhor.] Tipo assim, eu tou lá, eu e minha amigas. Aí a gente começa a conversar e tal, aí uma sai da mesa e o pessoal já começa a falar dela: 'Ah, você viu a fulana, não respeita ninguém'. Ou então passa alguém na rua e já fala: 'Ah, passou a fulana paquerando'; 'Ah, cê viu? Ah, nunca achei que aquela pessoa ia fazer isso'. (Fernanda, 25 anos)

Castañeda (2006, p. 221) pontua que, "independentemente de qualquer consideração biológica, existem em quase todos os países, expectativas e padrões diferentes para homens e mulheres, que conferem aos primeiros uma liberdade muito maior". Porém, a autora lembra que os países industrializados atualmente apresentam locais de encontro nos quais lésbicas podem relacionar-se livremente. São espaços direcionados especificamente a elas, onde podem flertar, namorar e até ter práticas sexuais em ambientes privados denominados darkrooms, muito popularizados entre gays desde os anos 1980. "Portanto, começamos a ver, em lésbicas, padrões de conduta sexual cada vez mais parecidos aos do outro sexo" (Castañeda, 2006, p. 41-42). Janaína fala sobre esse desprendimento libertário sexual com uma metáfora, criticando a infidelidade na relação:

Tem mulheres também. A gente vê umas espingarda por aí, a pessoa tá, às vezes, com o caso [a namorada] do lado e tá atirando do lado, do outro, do outro [flertando com várias pessoas]. Gente, que que é isso? Respeita a pessoa que tem. Se não tá contente, dispensa a pessoa primeiro, depois corre atrás do prejuízo, você entendeu? (Janaína, 47 anos)

Eduarda também aponta essa questão na fala de amigas heterossexuais: 
[...] meninas heterossexuais que não sabem que eu sou lésbica vêm falar pra mim [...]: 'Nossa, lésbicas, vocể já viu? Eununca vi, que grupo de meninas mais estranhas, um dia tão com uma, um dia tão com outra, na mesma semana ficam com três, na mesma noite. Nossa senhora!'. (Eduarda, 18 anos)

A liberdade sexual parece se apresentar de forma mais assídua nas vivências de mulheres lésbicas, especialmente entre as mais jovens, comparativamente às heterossexuais. De acordo com Pérez (2000, p. 5-6), "Giddens (1995) considera que as mulheres lésbicas rompem o estereótipo de que as mulheres são por natureza monógamas, apesar de um bom número delas considerarem a monogamia como um ideal desejável em uma relação". Porém, pode-se pensar, ainda, sobre o que a autora lembra como monogamia seriada - algo extremamente comum no universo lésbico (Vencato, 2005, p. 55) -, ou seja, o estabelecimento de um relacionamento com alguém do grupo, que, ao terminar, é re-estabelecido com outra do mesmo grupo. Isso ocorre devido à invisibilidade lésbica que dificulta maior abrangência nas relações:

A prática do troca-troca [de parceiras dentro de um mesmo grupo] é, inclusive, bastante discutida nesse meio: sempre citada jocosamente, muito criticada e pouco defendida. Há argumentos que tentam defender essa prática, que normalmente falam da ausência de mulheres disponíveis no mercado, o que estimularia esta certa endogamia afetivo-sexual. [...] $\mathrm{O}$ argumento contrário à prática mais extremista afirma que é este tipo de comportamento que dá base à idéia de promiscuidade no universo homossexual feminino e que, nesse contexto, a prática aumenta o preconceito contra as mulheres. (Vencato, 2005, p. 55-56)

Sobre isso, Castañeda (2007, p. 198-200) afirma que, entre os homossexuais, muito mais que entre os heterossexuais, os limites entre sexo, amor e amizade não são muito claros. Com os homossexuais, tanto 
"as mulheres como os homens têm, às vezes, relações sexuais com os seus amigos (ou os parceiros dos seus amigos), inclusive aqueles que eles consideram a sua 'família'. Até mesmo se falou do sumiço do tabu do incesto na cultura gay". Especialmente entre os gays, a liberação sexual permitiu que as relações eróticas não fossem "necessariamente um sinal de amor, intimidade ou engajamento. A relação sexual pode ser um modo de se conhecer, de aprofundar uma amizade, ou de passar um bom momento entre amigos". A autora lembra, ainda, que se trata de falta de oportunidades decorrentes, claro, da homofobia que não aceita essa e outras formas de expressão das sexualidades a não ser a heterossexualidade, sendo que, mesmo nessa, dependendo do contexto, certos padrões e normas também são muito rígidos. Especificamente na adolescência, período em que é menos provável que os homossexuais possam se declarar na escola ou no grupo de amigos heterossexuais (que são a maioria), e, assim, por falta de opção, acabam relacionando-se com pessoas do mesmo grupo. Em relação aos gays, por conta de serem homens e terem um código de virilidade a cumprir, as relações sexuais podem ser mais comuns comparativamente às mulheres lésbicas.

Ainda segundo Castañeda (2007, p. 198-200), entre as mulheres, mesmo que usufruam, "hoje, de uma liberdade sexual que as mulheres nunca haviam conhecido antes [...] muito mais libertas que as heterossexuais", essa dinâmica não se dá de forma tão tranqüila entre elas como entre os homens homossexuais, devido à mesma construção da sexualidade feminina: "não porque elas são menos maduras ou 'razoáveis' do que os homens, mas porque os homens têm muito mais experiência nesse campo" de liberdade de vivência de sua sexualidade.

Em relação à fidelidade, Marina, diferentemente de Marcela e Janaína, disse que, seja um casal hetero ou homossexual, entre homens ou entre mulheres, não considera que há diferenciação:

Eu acho que relacionamento é relacionamento. Eu não diferencio um do outro... nem homem com homem, nem mulher com mulher, nem homem com mulher, mulher com 
homem, acho que é tudo igual. Tem milhares de homens traindo mulheres, mulheres traindo homens, mulheres que traem mulherese bomens que traem homens. (Marina, 23 anos)

E Eduarda já aponta para uma desconstrução do entendimento da infidelidade, questionando a idéia de traição a partir de relacionamentos abertos, sem esquecer a igualdade de decisão entre as parceiras:

[...] eu acho que quando se firma um compromisso, quando se verbaliza: estamos namorando, então, estão namorando, duas menininhas. Tem que ser fiel, eu acho, tem que tentar pelo menos. Em consideração ao outro. Respeito, sabe? Agora, quando você conversa com a outra. Tudo depende da conversa. Se você conversou tudo, e essa questão da fidelidade não e tão relevante assim, ou se as duas se permitem relacionamentos com outras meninas, tudo bem! Tem que se uma coisa que as duas sabem e estejam de acordo. (Eduarda, 18 anos).

Pode-se dizer, juntamente com Heilborn (2004), de dois modelos de relacionamento: o tradicional e o moderno. O primeiro pautado na questão da fidelidade e monogamia, enquanto, no segundo, não apenas "as relações extraconjugais são admitidas para ambos os parceiros, dissolvendo-se por completo a idéia de um 'duplo padrão de moralidade' (Pitt-Rivers, 1977') como o entendimento do que constitui a fidelidade altera-se. Fala-se em lealdade" (Heilborn, 2004, p. 112). O que se pode perceber entre as entrevistadas, que influenciou muito seus discursos, foi uma clara liberação erótico-sexual pessoal entre as mais jovens (muito mais em discurso que em vivência), aproximando-se mais do modelo moderno, e algumas restrições pessoais entre àquelas com mais de 40 anos, aproximando-se mais do modelo tradicional.

${ }^{9}$ PITT-RIVERS, J. The fate of sheschen or the politics of sex. Cambridge, Cambrige University Press, 1977.

Temáticas, Campinas, 20(40): PG-PG, ago./dez. 2012 
Para essas últimas, existe forte ligação entre afetividade e desejo sexual: Olha, eu vou falar de mim. Eu só fico se tiver gostando, eu não fico por ficar. Não fico por ficar. Até já tentei, mas eu não consigo. Não consigo. Eu, pra ficar com uma mulher, tem que, você entendeu, sentir um algo, um algo a mais, senão eu não fico, não fico. E também não é por toda mulher que eu me interesso. Eu tenho amigas, eu tou dizendo isso porque a gente chega a comentar, às vezes eu sento com várias amigas, e elas falam: 'Nossa! fiquei com tantas. Nossa! fiquei com três na noite'. Eu falo: 'Mas, gente, como que vocês conseguem?'. (Janaína, 47 anos)

[Você acha que na relação entre lésbicas, elas ficam por ficar?] $A$ h, não... eu acho que tem que rolar a química, né? Eu não ficaria. Não ficaria com mulher alguma se não rolasse alguma coisa. A não ser assim, numa festa, num barzinho, ta todo mundo, né, chapando o coco, aí dá uns beijo só pra não passar em branco. [risos] Mas pra rolar, eu mesmo, pra rolar uma cama comigo tem que rolar uma química. Senão eu não consigo. Não adianta. [Você não transaria só por diversão] Não, não faria isso. [Mas você vê que isso acontece na relação entre mulheres] Com certeza. Já se conheceu aqui e daqui a pouco o bicho ta pegando, mas eu não curto. (Marcela, 42 anos)

Apesar de dar muita importância à afetividade e colocá-la como condicional ao desejo sexual, Marcela não desqualifica esse último:

Ó, é o que te falei, que a mulher em si ela tem muito mais amor... só que sexo também éfundamental. [Então você não conseguiria continuar uma relação que a sua namorada quisesse transar só de vez em quando?] Ah, aí não tem como, porque se você ama uma pessoa você tem que transar pelo menos três vezes ao dia [risos jocosos] Se for uma vez por mês não tem como, aí não tem amor! (Marcela, 42 anos)

Janaína, ao contrário, apenas envolve-se sexualmente com alguém a partir de um romantismo: 
[...] eu sou muito romântica, e digo que até meio ignorante com algumas coisas, conservadora, não sei, mas eu ainda gosto do flerte, gosto daquela coisa de você tocar e sentir aquela coisa gostosa, ou nem tocar, só de chegar perto e conversar, aquela coisa prazerosa, você entendeu? [Uma coisa que só acontece quando você está a fim.] Sim, sim, e não simplesmente porque é a minha necessidade sexual que eu vou descarregar, não. Até porque eu não tenho isso, se eu não ficar a fim, também não me estimula sexualmente. De forma alguma. (Janaína, 47 anos)

As mulheres em torno de 18 a 25 anos aparentam um discurso mais flexível em relação às normas sociais preestabelecidas, se comparadas àquelas com mais de 40 anos. Uma das diferenças foi que as entrevistadas de 18 a 25 anos mostraram, discursivamente, maior aceitação às formas de diversidades de experiência das sexualidades menos tradicionais - não monogamia, relacionamentos abertos, experiências eróticas e sexuais sem necessário envolvimento afetivo e pluriparceria homoerótica (namorar ou ficar com várias pessoas). Apesar disso, o ideal de todas elas pareceu ser por um relacionamento monogâmico e estável. Para Eduarda, Marina e Fernanda, experiências eróticas ( $f i c a r$ ) podem se dar sem o envolvimento afetivo, indiferenciando o sexo ou a identidade sexual da pessoa: "acho normal, por uma coisa física, sexual, ali no momento. Você não precisa estar apaixonado, amando a pessoa para ficar atraído por ela. Não precisa. Isso com qualquer um" (Eduarda, 18 anos); "É a mesma coisa, é igual. Não dá pra colocar que porque é lésbica é diferente. É a pessoa! Eu já beijei mulher por beijar, por nada, beijar duas, três, tudo" (Marina, 23 anos); "I ...fica-se só por ficar, sem estar gostando?] Sim, atração, só desejo" (Fernanda, 25 anos).

Sobre atos sexuais, Marina relatou uma experiência, porém não diz ser seu desejo: "Eu nunca transei por transar, assim, mas... não, mentira, aprimeira vez foi, na verdade, éporquefoi aprimeira vez, assim... Mas, assim, éamesma coisa. É tudo igual, é a relação" (Marina, 23 anos). Eduarda, já tranquilamente, posiciona-se como se permitindo experiências sexuais por prazer, sem envolvimento afetivo: "Eu não digo na maioria, pormim poderser. Eutransariasem 
estar amando, só por prazer” (Eduarda, 18 anos). Sobre isso, Vencato (2005, p. 57) diz que o seriado The $L$ Word $^{10}$ tem algo a dizer acerca do universo lésbico: "que mulheres fazem sexo por diversão [e] que há mulheres que têm várias parceiras sexuais ao longo da vida", subvertendo as normas sociais de feminilidade.

A partir desses relatos, o que se vê aqui é a existência controversa de dois estigmas praticamente opostos sobre as lesbianidades que têm explicações nos referentes: heterocentrismo, falocentrismo e machismo. É possível perceber como a dinâmica do biopoder ${ }^{11}$ (Foucault, 1988), ou seja, de uma organização do poder sobre a vida, atravessa as relações das pessoas independentemente de seus vínculos, tentando condicioná-las às normas sociais de gênero. Contudo, nota-se, também, que é possível fugir a essas normatizações.

Por um lado, os discursos que elas ouvem sobre si mesmas apontam que a relação entre mulheres é uma mais pautada nos sentimentos, desejo por um relacionamento estável em uma "irmandade" (que corrobora a inexistência do ato sexual entre elas), e que o sexo está sempre em segundo lugar, devido à "natureza" feminina voltada aos cuidados com uma parceira, ou seja, um sentimento maternal "próprio" das mulheres (Badinter, 1986). Por outro lado, é posta a questão da patologia elaborada pelos cientistas sobre a homossexualidade como perversão sexual, da visão religiosa de pecado da luxúria e da atuação pornográfica direcionada ao desejo sexual dos homens, categorizando as lésbicas como promíscuas. Ambos os discursos traduzem-se em ilegitimidade do relacionamento afetivo-sexual

\footnotetext{
${ }^{10}$ The L Word é um seriado dramático da televisão a cabo dos Estados Unidos, que mostra as vidas de um grupo de amigas lésbicas e bissexuais que vivem na cidade de Los Angeles, Califórnia. Série criada por Ilene Chaiken. Site: http://www.thelwordonline.com.

${ }^{11}$ Esse poder exercido pela inventividade e produção de métodos e procedimentos de controle sobre os corpos surgiu, a partir do início do século XIX, com o aparecimento das tecnologias médicas de sexo. Desse modo, as populações passaram a ser normalizadas e controladas segundo os valores burgueses e capitalistas, os quais, através do dispositivo da sexualidade, naturalizam e reificam o sistema sexo (divididos em macho ou fêmea), gênero (separados em masculino ou feminino) e desejo/práticas sexuais (entendidos como heterossexual ou homossexual) (Foucault, 1988, p. 100).
} 
entre lésbicas. Marina exemplifica como essa relação é apreendida como sem validade, estabilidade ou compromisso.

\begin{abstract}
Ah, eu já ouvi falar assim, se é lésbica não conta. Que não conta o relacionamento. Tem muita gente que acha que se o relacionamento é entre duas mulheres logo ela vai acabar traindo, sabe? De ter cara que eu já tinha ficado chegar pra mim e falar: 'Ah, agora que você está namorando uma menina, então tá beleza, a gente pode ficar'. Assim falando zuando, mas sempre com as segundas intenções. [Como se o relacionamento não tivesse validade?] É, por aí. De falar que se mulher que fica com outra mulher, então fica com homem, fica com outra mulher, por aí. (Marina, 23 anos)
\end{abstract}

É interessante pensar na arbitrariedade dos discursos quando se discorre sobre as lesbianidades a partir do sistema heterossexual, utilizando duas figuras legitimadas do feminino no âmbito das sexualidades: a mulher qualquer e a mulher do homem.

Primeiro, a mulher qualquer, a desconhecida, a "usável", aquela que se liga aos homens pelo desejo sexual (por exemplo, a puta) é vista como objeto de satisfação do homem. Satisfazer um homem é dever delas. E sendo um objeto, não se pensa que ela pode satisfazer (amorosa ou sexualmente) outra mulher.

Segundo, e lembrando que as mulheres não são "anestesiadas" e têm desejo sexual e de relacionar-se, a mulher do homem, a conhecida, a "respeitável", aquela que se liga a ele por laços afetivos (a namorada, a esposa) é vista como sendo satisfeita apenas por um homem, pois este é o sujeito ativo da satisfação sexual e amorosa - eles detêm o poder no âmbito das sexualidades e das relações. Uma mulher não é vista como sujeito, ela é satisfeita por um. Essa visão também impossibilita a compreensão de que uma mulher possa satisfazer outra. Em ambos os casos, a mulher é objeto e o homem é sujeito. Assim, as lesbianidades não se encaixam em nenhuma imagem legitimada de mulher: ou a mulher é vista como objeto que satisfaça o homem, ou o homem como capacitado a satisfazer seus desejos 
sexuais. As lesbianidades acabam por romper com essa perspectiva por trazer, na relação entre duas mulheres, o sujeito e o objeto de satisfação ao mesmo tempo, sendo, por isso, desacreditada.

Os estigmas sobre as lesbianidades, como ferramentas de controle do biopoder, baseadas no machismo, fazem essa forma de vivência sexual visível dessas formas para que continuem sendo invisíveis em suas variedades de existência. "O lesbianismo é um segredo, não aparece, é invisível, mas, ao mesmo tempo, é constantemente exposto à luz pública, como um subtexto evidente" (Gimeno Reinoso, 2005, p. 294) ${ }^{12}$, apagando todas as suas outras multiplicidades incompatíveis com o viriarcado. É a partir de seu próprio discurso que mulheres que vivenciam as lesbianidades podem mostrar que ser lésbica é construir outras formas de subjetivação de ser mulher.

\section{REFERÊNCIAS BIBLIOGRÁFICAS}

ALMEIDA, Miguel Valle de. O casamento entre pessoas do mesmo sexo. Sobre "gentes remotas e estranhas" numa "sociedade decente". Revista Crítica de Ciências Sociais (76), pp. 17-31, dez. 2006.

BADINTER, E. Um amor conquistado: o mito do amor materno. Tradução Waltensin Dutra. Rio de Janeiro, Nova Fronteira, 1986.

BORDIEU, P. Novas reflexões sobre a dominação masculina. In: LOPES, M.J.M; MEYER, D. E.; WALDOW, V. R. (Orgs.). Gênero e Saúde, Porto Alegre, Artes Médicas, pp. 28-40, 1996.

BORGES, Lenise Santana. Lesbianidade na TV: visibilidade e "apagamento" em telenovelas brasileiras. In: GROSSI, Miriam Pillar; UZIEL, Anna Paula, MELLO, Luiz (Orgs.) Conjugalidades, parentalidades e

\footnotetext{
${ }^{12}$ Minha versão do original em espanhol: "El lesbianismo es un secreto, no aparece, es invisible, pero, al mismo tiempo, es constantemente expuesto a la luz pública, como un subtexto evidente" (GIMENO REINOSO, 2005, p. 294).
} 
identidades lésbicas, gays e travestis. (Coleção Sexualidade, gênero e sociedade). Rio de Janeiro: Garamond, pp. 363-384, 2007.

BUTLER, J. Corpos que pesam: sobre os limites discursivos do "sexo". In: LOURO, G. L. (Org.). O corpo educado: pedagogias da sexualidade. Tradução Tomaz Tadeu da Silva. Belo Horizonte, Autêntica, 2000. pp. 151-172.

BUTLER, J. Problemas de gênero: feminismo e subversão da identidade. Tradução Renato Aguiar. Rio de Janeiro, Civilização Brasileira, 2003a.

O casamento é sempre tido como heterossexual? Cadernos Pagu (21), pp. 219-260, 2003b.

CASTAÑEDA, M. O machismo invisível. Tradução Lara Christina de Malimpensa. São Paulo, A Girafa Editora, 2006.

A experiência homossexual: explicações e conselhos para os homossexuais, suas familias e seus terapeutas. Tradução Brigitte Hervot e Fernando Silva Teixeira Filho. São Paulo, A Girafa Editora, 2007.

ERIBON, Didier. Reflexões sobre a questão gay. Rio de Janeiro: Companhia de Freud, 2008.

FOUCAULT, M. História da sexualidade I: a vontade de saber. Rio de Janeiro: Graal, 1988.

FOUCAULT, M. Microfísica do poder. Tradução Roberto Machado. (22 ed.), Rio de Janeiro, Graal, 1979.

GIMENO REINOSO, B. Historia y análisis político del lesbianismo: la liberación de una generación. (Colección Libertad y Cambio) Editorial Gedisa, Barcelona, España, 2005.

GOFFMAN, E. Estigma: notas sobre a manipulação da identidade deteriorada. Rio de Janeiro: Zahar, 1975.

GOMIDE, Silvia. Formação da identidade lésbica: do silêncio ao queer. In: GROSSI, Miriam Pillar; UZIEL, Anna Paula, MELLO, Luiz (Orgs.) Conjugalidades, parentalidades e identidades lésbicas, gays e travestis. 
(Coleção Sexualidade, gênero e sociedade). Rio de Janeiro: Garamond, 2007. pp. 405-423.

GUATTARI, F.; ROLNIK, S. Micropolitica: cartografias do desejo. Petrópolis, RJ: Vozes, 1996.

HEILBORN, M. L. Dois é par: gênero e identidade sexual em contexto igualitário. Rio de Janeiro, Garamond (Coleção Sexualidade, gênero e sociedade. Homossexualidade e cultura), 2004.

HELMINIAK, D. A. O que a Bíblia realmente diz sobre a homossexualidade. Tradução Eduardo Teixeira Nunes. São Paulo, Summus, 1988.

KATZ, J. N. A invenção da heterossexualidade. Tradução Clara Fernandes. Rio de Janeiro: Ediouro, 1996.

LESSA, P. Que 'babado' é esse? Corpo, sexualidade e lesbiandade no gay pride. Labrys, estudos feministas (6), ago./dez., 2004. Disponível em: <http://www.unb.br/ih/his/gefem/labrys6/lesb/patricia.htm>. Acesso em: 18 out. 2007.

LOURO, G. L. Pedagogias da Sexualidade. In: (Org.). O corpo educado: pedagogias da sexualidade. Tradução Tomaz Tadeu da Silva. Belo Horizonte, Autêntica. pp. 07-34, 2000.

MISKOLCI, Richard. Pânicos morais e controle social - reflexões sobre o casamento gay. Cadernos Pagu (28), pp. 101-128, jan./jun. 2007.

NAVARRO-SWAIN, T. O normal e o "abjeto": a heterossexualidade compulsória e o destino biológico das mulheres. Labrys, estudos feministas (6), ago./dez., 2004. Disponível em: <http://www.unb.br/ ih/his/gefem/labrys6/lesb/anahita.htm>. Acesso em: 13 mai. 2008.

OLIVEIRA, Vanilda Maria de Oliveira. Identidades interseccionais e militâncias políticas. In: GROSSI, Miriam Pillar; UZIEL, Anna Paula, MELLO,Luiz (Orgs.) Conjugalidades, parentalidadese identidades lésbicas, gays e travestis. (Coleção Sexualidade, gênero e sociedade). Rio de Janeiro: Garamond, pp. 385-404, 2007. 
PAIVA, Antônio Crístian Saraiva. Reserva e invisibilidade: a construção da homossexualidade numa perspectiva micropolítica. In: GROSSI, Miriam Pillar; UZIEL, Anna Paula, MELLO, Luiz (Orgs.) Conjugalidades, parentalidadeseidentidadeslésbicas, gays se travestis. (Coleção Sexualidade, gênero e sociedade). Rio de Janeiro: Garamond, pp. 23-46, 2007.

PÉREZ, G. C. Relaciones entre mujeres. [2000]. Disponível em: $<$ http://www.ciudadaniasexual.org/publicaciones/5.pdf $>$. Acesso em: 25 jan. 2007.

PORTINARI, D. Odiscurso da homossexualidadefeminina. São Paulo, Brasiliense, 1989.

REVISTA CLÁUDIA. Amor entre mulheres. n. 441, São Paulo, Editora Abril, jun, 1998, pp. 170-175.

ROTELLO, G. Comportamento Sexual e AIDS: a cultura gay em transformação. São Paulo, GLS, 1998.

RUBIN, G. BUTLER, J. Tráfico sexual - entrevista. Cadernos Pagu (21), Campinas-SP, pp. 157-209, 2003.

RUBIN, G. S. O tráfico de mulheres: notas sobre a economia política do sexo. Tradução ONG SOS Corpo (Recife), policopiada. Publicada originariamente como The traffic in women: notes on the political economy of sex. In: REITER, R. (Org.) Toward an anthropology of women. New York, Monthly Review Press. pp. 157-210, 1975+.

SOUZA, Débora H. Amor solitário: uma análise dentro da perspectiva do gênero. Revista Ártemis (7) pp. 23-35, dez. 2007.

Thinking sex: notes for a radical theory of the politics of sexuality. NARDI, P. M.; SCHNEIDER, B. E. (Ed.) Social perspectives in lesbian and gay studies: a reader. New York, Routledge, 1998. pp. 100-133. Publicada originariamente In: Carol S. Vance. Pleasure and Danger: Exploring Female Sexuality, 1984. 
VENCATO, A. P. “Algumas garotas preferem garotas": The L Word, sexualidade e as políticas de visibilidade lésbica. TCC "Tópicos Especiais em Saúde Coletiva: novos temas na abordagem Sócio-Antropológica da Sexualidade", Programa de Pós-Graduação em Saúde Coletiva - IMS - Universidade Federal do Rio de Janeiro, UFRJ, 2005.

WATREMEZ, V. Ampliação do quadro de análise feminista da violência doméstica masculina através do estudo da violência nas relações lesbianas. Tradução Tânia Navarro-Swain. Labrys, estudos feministas (1-2), jul./dez., 2002. Desponível em: <http://www.unb.br/ih/his/ gefem/labrys1_2/index.html>. Acesso em:14 mai. 2008.

WEID, Olívia Von Der. Gênero, corpo e sexualidade: um estudo antropológico sobre a troca de casais. Revista Ártemis, 5, pp. 1-15, dez. 2006.

WELZER-LANG, D. The construction of the masculine: women's domination and homophobia. Revista de Estudos Feministas, Florianópolis, v.9, n. 2, pp. 460-482, 2001. 